\title{
The Muscle Immobility of Depression-The Weightlessness Within
}

\author{
Berislav Momčilović ${ }^{1 *}$, Juraj Prejac ${ }^{2}$, Vjeran Višnjević ${ }^{1}$, Stipe Drmić ${ }^{3}$, Ninoslav Mimica ${ }^{4}$, \\ Željka Bukovec-Megla ${ }^{5}$, Sanja Brundić ${ }^{1}$, Anatoly Viktorovich Skalny ${ }^{6}$ \\ ${ }^{1}$ Institute for Research and Development of the Sustainable Eco Systems, Zagreb, Croatia \\ ${ }^{2}$ University Hospital Centre Zagreb, Zagreb, Croatia \\ ${ }^{3}$ Neuropsychiatric Hospital "Dr. Ivan Barbot”, Popovača, Croatia \\ ${ }^{4}$ University Psychiatric Hospital, Zagreb, Croatia \\ ${ }^{5}$ Laboratory of Endocrinology, Clinic of Oncology and Nuclear Medicine, \\ University Hospital Center "Sestre milosrdnice", Zagreb, Croatia \\ ${ }^{6}$ ANO Center for Biotic Medicine, Moscow, Russia \\ Email: "berislav.momcilovic@gmail.com, juraj.prejac@gmail.com, vjeranv@gmail.com, \\ stipe.drmic@gmail.com, ninoslav.mimica@bolnica-vrapce.hr, zeljka.bukovec@kbcsm.hr, \\ sanja.brundic@gmail.com, skalny3@orc.ru
}

Received June $4^{\text {th }}, 2012$; revised July $10^{\text {th }}, 2012$; accepted August $7^{\text {th }}, 2012$

\begin{abstract}
The purpose of the study was to elucidate the role of bioelements in human depression. We studied hair sodium and potassium in 311 adult subjects (188 women and $123 \mathrm{men}$ ) in the randomized, prospective, observational study; 192 were controls ( 83 men and 109 women), and 119 have major unipolar depression (40 men and 79 women). Depression was diagnosed by the DSM-IV criteria, and hair sodium and potassium were analyzed by the inductively coupled plasma atomic emission spectroscopy (ICP AES). In the subgroup of 19 controls and 24 depressed subjects who attempted suicide (the gravest form of major depression), antidiuretic hormone (ADH) was assessed by using the standard laboratory ADH diagnostic kit. Significant gender differences were observed, since men have more hair $\mathrm{Na}$ and $\mathrm{K}$ than women $\mathrm{Na} p$ $<.01 ; \mathrm{K} p<.02$; Chi square test). The depressed subjects also have increased levels of hair $\mathrm{Na}$ and $\mathrm{K}$, what indicate the negative balance of these electrolytes, since hair growth is unidirectional $(p<.01$ for both $\mathrm{K}$ and $\mathrm{Na}$, Chi square test); $\mathrm{ADH}$ values were decreased in the suicidal subgroup $(p<.01$, Chi square test). These results on negative $\mathrm{Na}$ and $\mathrm{K}$ balance, and decreased $\mathrm{ADH}$ in depression, are pattern-identical to those observed in astronauts after the short term Apollo space missions. The question emerges if the observed Earthly metabolic changes of body muscles in depressed subjects are the direct consequence of the muscle inactivity, or the fatigue of depression is mediated by the failure of some hypothetical, gravity dependent muscle mobility brain control "dynamostat" that operates in conjunction with the fluid regulation center that manifest its presence when being weightless in the Space.
\end{abstract}

Keywords: Depression; Suicide; Hair; Blood; Sodium; Potassium; Vasopressin; Muscle Immobility; Weightlessness

\section{Introduction}

Today, depression, and unipolar major depression in particular, is the most prevalent mental health impairment of the mankind (Kaplan \& Sadock, 1995; Wong, 2005); the condition being twice as high in women as compared to men (Kessler et al., 1993). In medical terms depression is the core affective component of the mood disorders (The Merck Manual of Diagnosis and Therapy, 1999). Indeed, unipolar depression is considered to be the condition of common and complex disorder of gene-environment interactions for which the specific and environmental substrates are still unknown (Licino \& Wong, 2005).

The semi-quantitative exploratory data analysis on a smaller population sample revealed that the multielement profile of hair is changed in depressed as compared to the control subjects (Momčilović et al., 2008, Momčilović et al., 2010). These preliminary studies showed, and to our surprise, that the greatest

${ }^{*}$ Corresponding author. change involved the negative balance of the major electrolytes $\mathrm{Na}$ and $\mathrm{K}$ in the depressed subjects. The aim of this study was to further scrutinize the reality of the observed phenomenon of depression related negative hair $\mathrm{Na}$ and $\mathrm{K}$ balance, and to explore the separate role of gender and depression on $\mathrm{Na}$ and $\mathrm{K}$ metabolism. A subgroup of gravely depressed subjects who attempted suicide (Wulsin, 1996) was also included to assess the possible changes in the depression related antidiuretic hormone $(\mathrm{ADH})$ secretion.

\section{Subjects and Methods}

Participants. This study was approved by the IRES Local Ethical Committee and it was conducted by strict adherence to the Declaration of Helsinki on Human Subject Research (Brown, 2009), and to the complementary Croatian national bylaws and regulations; every subject gave his written consent to participate in the study (Momčilović, 2011). No human research study in Croatia can be approved and funded without the clearance from the responsible Ethic Committee. 
We studied hair sodium and potassium in 311 adult subjects (188 women and 123 men) in the randomized, prospective, observational study; 192 were controls (83 men and 109 women), and 119 have major unipolar depression (40 men and 79 women). Depression was diagnosed in the outpatient psychiatric office by the licensed psychiatrists who followed the DSMIV criteria (APA 2000). Most of the control and depressed subjects have lived in Zagreb, the capital of Croatia; the control subjects were those who were concerned about their health and well-being.

Methods and Procedures. The scalp hair was collected over the easily palpable bony prominence at the back of the head (lat. protuberantia occipitalis externa); whole blood was collected by a venous puncture. Hair sodium $(\mathrm{H} \cdot \mathrm{Na})$ and potassium $(\mathrm{H} \cdot \mathrm{K})$, and whole blood sodium $(\mathrm{WB} \cdot \mathrm{Na})$ and potassium $(\mathrm{WB} \cdot \mathrm{K})$ were analyzed by the inductively coupled plasma atomic emission spectroscopy (ICP AES) at the Center for Biotic Medicine, Moscow, Russia; an ISO certified high-tech laboratory, as already reported in a great detail (Momčilović et al., 2006). All the results are expressed in $\mu \mathrm{g} \cdot \mathrm{g}^{-1}$.

The CBM detection limits for hair $\mathrm{Na}$ and $\mathrm{K}$ were $7.5 \mu \mathrm{g} \cdot \mathrm{g}^{-1}$ and.45 $\mu \mathrm{g} \cdot \mathrm{g}^{-1}$, respectively. The normal CBM ranges for hair $\mathrm{Na}$ were $80-850 \mu \mathrm{g} \cdot \mathrm{g}^{-1}$ (men) and $50-250$ (women), and for hair $\mathrm{K}$ they were $50-250 \mu \mathrm{g} \cdot \mathrm{g}^{-1}$ (men) and $25-110 \mu \mathrm{g} \cdot \mathrm{g}^{-1}$ (women). The coefficient of variation for $\mathrm{Na}$ and $\mathrm{K}$ was $44 \%$ and 2.5\%, respectively (Momčilović et al., 2009). The Na pleiad is characterized by 25 isotopes $(1 \mathrm{O}, 2 \mathrm{~F}, 5 \mathrm{Ne}, 8 \mathrm{Na}, 4$ $\mathrm{Mg}, 4 \mathrm{Al}, 1 \mathrm{Si}$ ), and that of $\mathrm{K}$ by 40 isotopes ( $2 \mathrm{~S}, 4 \mathrm{Cl}, 6 \mathrm{Ar}, 9$ $\mathrm{K}, 8 \mathrm{Ca}, 8 \mathrm{Sc}, 3 \mathrm{Ti}$ ) (Momčilović et al., 2008).

In the subgroup of 19 controls and 24 depressed subjects who were admitted to hospital after the attempted suicide, antidiuretic hormone (ADH) was assessed in plasma with the radioimmunoassay (RIA) (Glick \& Kagan, 1979). Standard laboratory $\mathrm{ADH}$ diagnostic kit was used (Vasopressin Direct RIA, Buhlmann Laboratories AG, Schonenbuch, Switzerland); the manufacturer claimed normal vasopressin values (Mean $\pm \mathrm{SD}$ ) to $\mathrm{be} \leq 6.7 \mathrm{pg} \cdot \mathrm{mL}^{-1}$.

The results were expressed as either the median or the arithmetic mean with standard deviation. The different occurrence of $\mathrm{Na}$ and $\mathrm{K}$ in men and women and/or control and depressed subjects above and below the median were assessed with the Chi square test and MANOVA (Glantz, 2005). When there were gender difference between men and women, the frequency distribution of the median derivatives for $\mathrm{H} \cdot \mathrm{Na}$ and $\mathrm{H} \cdot \mathrm{K}$ concentrations were further scrutinized by fitting the logistic regression analysis function, for men and women separately:

$$
\mathrm{A} 2+(\mathrm{A} 1-\mathrm{A} 2) /\left(1+\left(\mathrm{x} / \mathrm{x}_{0}\right)^{p}\right)
$$

where A1 is initial value (lower horizontal asymptote), A2 is final value (upper horizontal asymptote), $\mathrm{x}_{0}$ is center (point of inflection; in our case it is the median $\mathrm{M}_{0}$ ), $p$ is power (the parameter that affects the slope of the area about the inflection point) (Appendix). We used the Qtiplot—Data Analysis and scientific visualization (www.soft.proindopendent.com/gbiplot.html) and Originpro 8.5.0 se 1 from Originlab Co., Northampton. MA, USA. The difference of $p<.05$ between the groups was considered to be significant.

\section{Results}

Hair Sodium and Potassium. We studied hair sodium and potassium in 311 adult subjects (188 women and $123 \mathrm{men}$ ) in the randomized, prospective, observational study; 192 were controls (83 men and 109 women), and 119 have major unipolar depression (40 men and 79 women). Sodium and potassium concentrations varied considerably for both men and women over a wide range of concentrations (Table 1). Visually, there appears to be some (statistically insignificant) tendency to accumulate more sodium and potassium in men than women, so that the median would be a better way of presenting the results than the arithmetic mean and the standard deviation/standard error (Figure 1). When data were log transformed (Figure 2) there appeared to be a gross difference between the lower median concentrations of hair sodium and potassium in women than men, respectively. That data frequency distribution indicates that sodium and potassium hair concentrations peak earlier in women than in men, i.e., that there is a gender dependent peak shift.
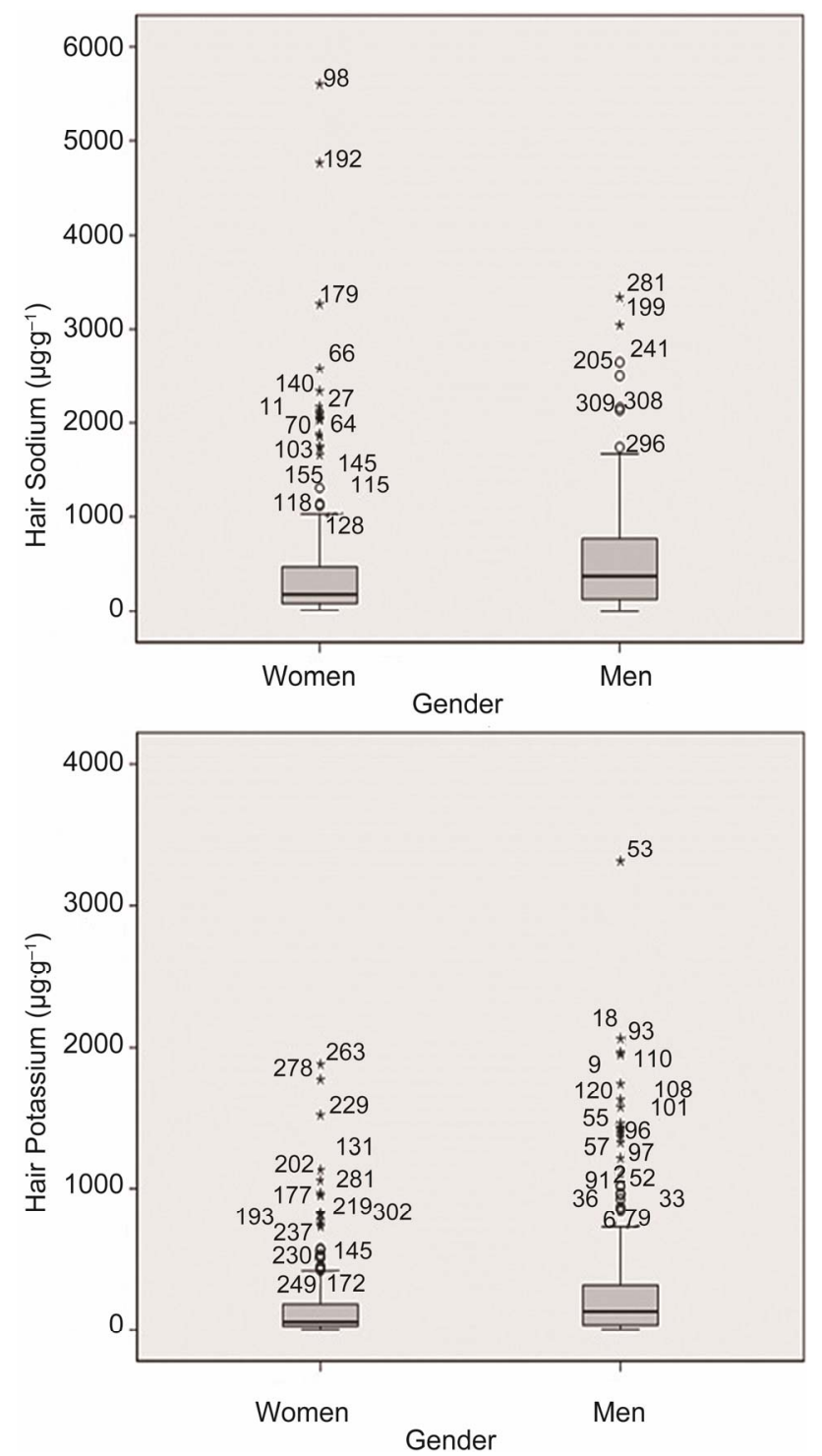

Figure 1.

Box and whisker plot for the hair sodium and potassium concentrations $\left(\mu \mathrm{g} \cdot \mathrm{g}^{-1}\right)$. Box 25 - 75 percentiles; bold line within in the box is median; whiskers are standard deviations; outliers are numbered according to the subjects study number. 
Table 1.

Hair sodium and potassium data $\left(\mu \mathrm{g} \cdot \mathrm{g}^{-1}\right)$.

\begin{tabular}{ccccccc}
\hline \multirow{2}{*}{ Subjects } & \multirow{2}{*}{$(\mathrm{n})$} & \multicolumn{2}{c}{ Sodium $(\mathrm{H} \cdot \mathrm{Na})$} & \multicolumn{2}{c}{ Potassium $(\mathrm{H} \cdot \mathrm{K})$} & $\mathrm{Na} / \mathrm{K}$ \\
\cline { 3 - 7 } & & Median & Range & Median & Range & Median \\
\hline Men & 123 & 376 & $7.50-3534$ & 130 & $1.53-3311$ & 2.89 \\
Women & 188 & 183 & $9.20-5606$ & 55.7 & $1.08-1882$ & 3.29 \\
All & 311 & 243 & $7.50-5606$ & 69.4 & $1.08-3311$ & 2.45 \\
\hline
\end{tabular}
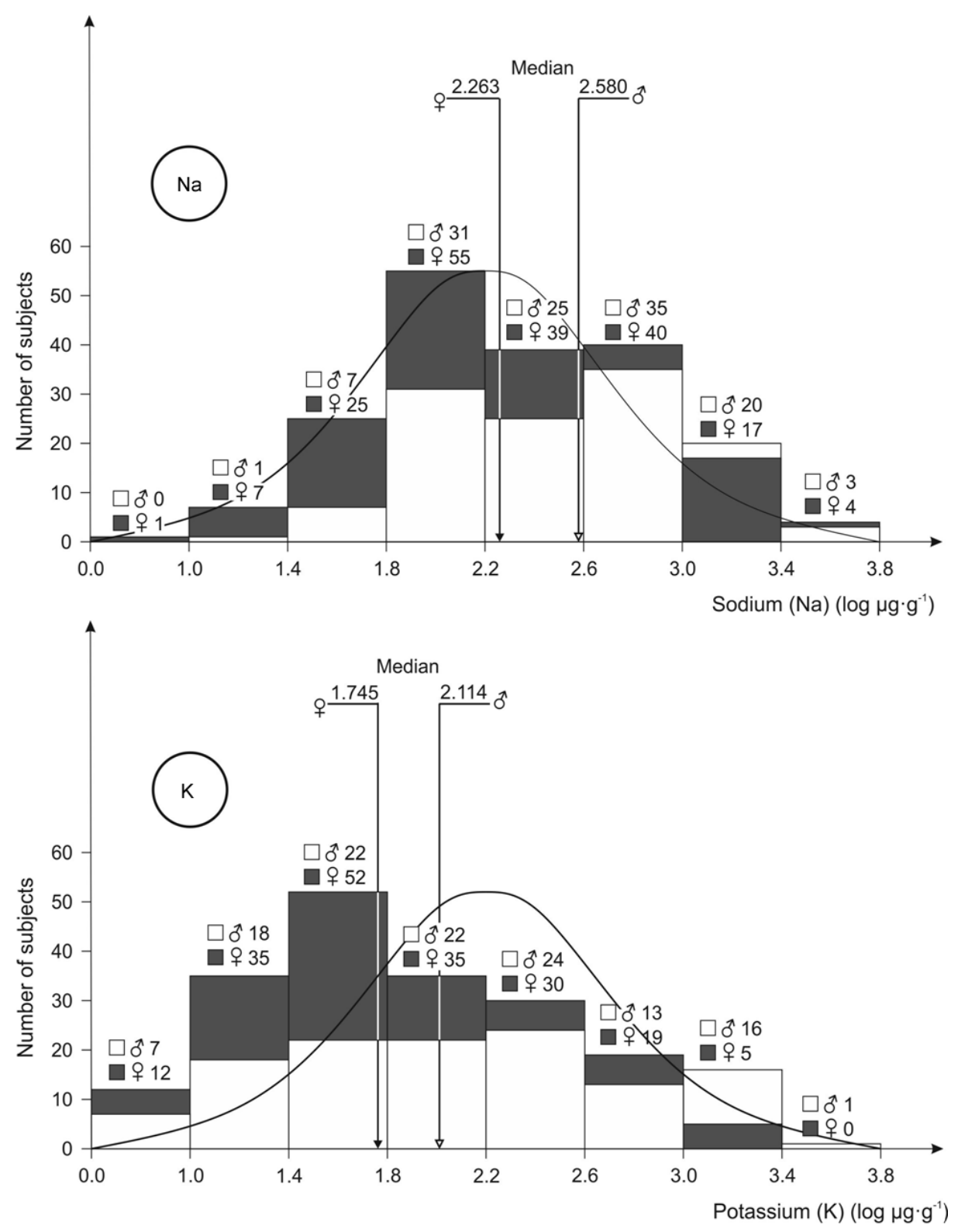

Figure 2.

Hair sodium (Na) and potassium (K) data frequency distribution $(\log ) . \square$ Men ( $\overbrace{}^{\circledR})$; $\square$ Women (ㅇ); $\nabla$ Median Men (Na 2.589, K 2.114); v Median Women (Na 2.263, K 1.745).

Gender. When we compared the frequency distribution of hair sodium and potassium concentrations above and below the median (Na 243 and $\mathrm{K} 69.4 \mu \mathrm{g} \cdot \mathrm{g}^{-1}$, Table 1), it become evident that men have more sodium and potassium in their hair than do the women ( $p<.01$ for both elements) (Table 2). Similarly, depressed subjects have more sodium and potassium in their hair than the control subjects (sodium $p<.02$, potassium $p$ $<$.01) (Table 3). MANOVA (not shown here) also confirmed this observation on gender and depression effect on hair potassium retention pattern, i.e., that men have more potassium in their hair than women and also that the depressed subjects have more potassium in the hair than the apparently healthy controls. 
Table 2.

Hair sodium and potassium accumulation depend upon the gender (data frequency).

\begin{tabular}{lcccc}
\hline & \multicolumn{2}{c}{ Sodium } & \multicolumn{2}{c}{ Potassium } \\
\cline { 2 - 5 } & Above median & Below median & Above median Below median \\
\hline Men & 74 & 49 & 73 & 50 \\
Women & 81 & 107 & 82 & 106 \\
Chi square test & \multicolumn{2}{c}{$p<.01$} & \multicolumn{3}{c}{$p<.01$} \\
\hline
\end{tabular}

Table 3.

Depression affects sodium and potassium hair deposition (data frequency).

\begin{tabular}{lcccc}
\hline & \multicolumn{2}{c}{ Sodium } & \multicolumn{2}{c}{ Potassium } \\
\cline { 2 - 5 } & Above median & Below median & Above median Below median \\
\hline Control & 85 & 107 & 81 & 111 \\
Depression & 70 & 49 & 74 & 45 \\
Chi square test & \multicolumn{2}{c}{$p<.02$} & \multicolumn{3}{c}{$p<.01$} \\
\hline
\end{tabular}

When it comes for sodium, MANOVA only weekly confirmed that depressed subjects have somewhat more sodium in their hair $(p<.10)$, and that men also tend to have more sodium than women in their hair $(p<.15)$.

Hair Sodium vs. Hair Potassium. The scatter plot of hair sodium vs. hair potassium showed different behavior if the subject was men or women and if he/she was depressed or not (Figure 3). The regression line was the steepest for men having depression (DM), but the lowest in control men (CM). In between these depressed men and control men there were both depressed and control groups of women, respectively. Again, the slope for the depressed women (DW) was slightly steeper than that of the control women $(\mathrm{CW})$. It should be noted that the correlation of sodium vs. potassium was much better in the depressed subjects $\left(\mathrm{DM} \mathrm{r}^{2}=.630\right.$, DW $\left.\mathrm{r}^{2}=.628\right)$ than in the

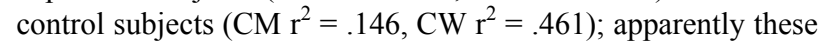
two elements did not significantly correlate in the control men subjects.

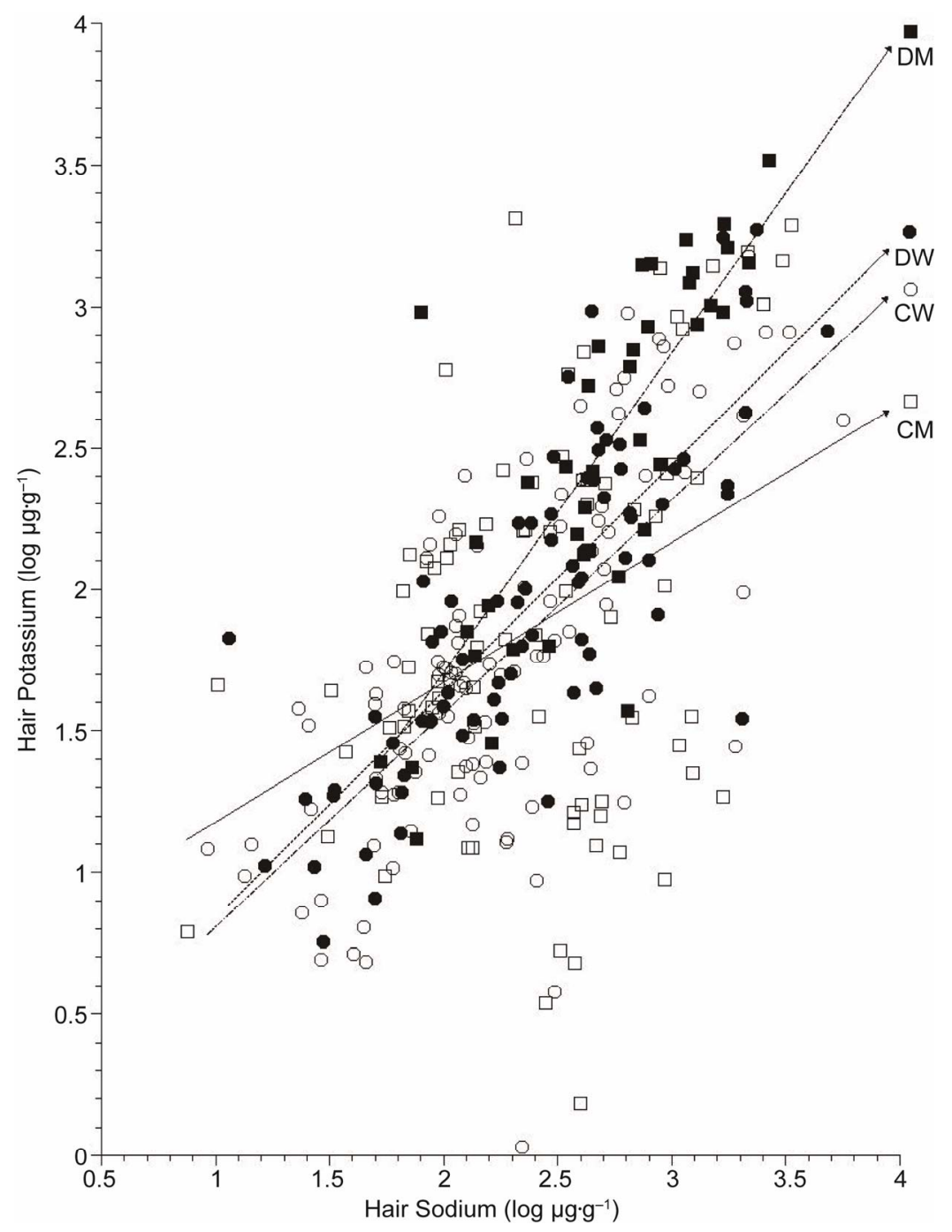

Figure 3.

Scatter plot of the hair sodium to potassium ( $\log \mathrm{Na}$ vs. $\log \mathrm{K})$. $\square \mathrm{CM}$ control men $(\mathrm{n}=83), \mathrm{Y}$ $=.494 \mathrm{X}+.682\left(\mathrm{r}^{2}=.146\right) ; \square \mathrm{DM}$ depressed men $(\mathrm{n}=40), \mathrm{Y}=1.130 \mathrm{X}+.628\left(\mathrm{r}^{2}=.628\right) ; \circ \mathrm{CW}$ control women $(\mathrm{n}=109), \mathrm{Y}=0.755 \mathrm{X}+0.053\left(\mathrm{r}^{2}=.461\right) ; \bullet \mathrm{DW}$ depressed women $(\mathrm{n}=79)$. $\mathrm{Y}$ $=.801 \mathrm{X}+.040\left(\mathrm{r}^{2}=.639\right)$. 
Blood Na and K. We also studied the scatter plot of whole blood sodium and potassium (Figure 4), with even the more disappointing result, i.e., the correlation appears to be nonexistent. By visual examination of the plot, we rather arbitrarily identified two clusters (boxed), one of them what we called Low sodium Low potassium cluster (bottom left), and a High sodium High potassium cluster (top right). Thus far we can only say that the High sodium High potassium cluster contained the slightly older subjects than the Low Sodium, Low potassium cluster $(p<.10)$.

Median Derivatives. Because of the observed gender difference, the frequency distribution of the median derivatives for $\mathrm{H} \cdot \mathrm{Na}$ and $\mathrm{H} \cdot \mathrm{K}$ concentrations was further scrutinized by fitting the logistic regression analysis function, for men and women separately (Figure 5, Left panel Na, Right panel K). Data to fit the equation are shown separately for sodium (Table 4), and potassium (Table 5). The $\mathrm{H} \cdot \mathrm{Na}$ below $28.8\left(\mathrm{~d}_{3}\right)$ and $56.5\left(\mathrm{D}_{3}\right)$ $\mu \mathrm{g} \cdot \mathrm{g}^{-1}$ for women and men, respectively, reflect low level of sodium intake. The adaptive, bioassay like physiological saturationn phase followed, where $\mathrm{H} \cdot \mathrm{Na}$ rose rapidly, first for women and then for men. Both, now separated parallel saturation curves, would converge and plateau above $909\left(\mathrm{u}_{2}\right)$ and $1223\left(\mathrm{U}_{2}\right) \mu \mathrm{g} \cdot \mathrm{g}^{-1}$ for women and men, respectively. Indeed, between these end points at the beginning and at the plateau, there were two distinct phase shifts saturation slopes for women and men, respectively. Women started to accumulate sodium in

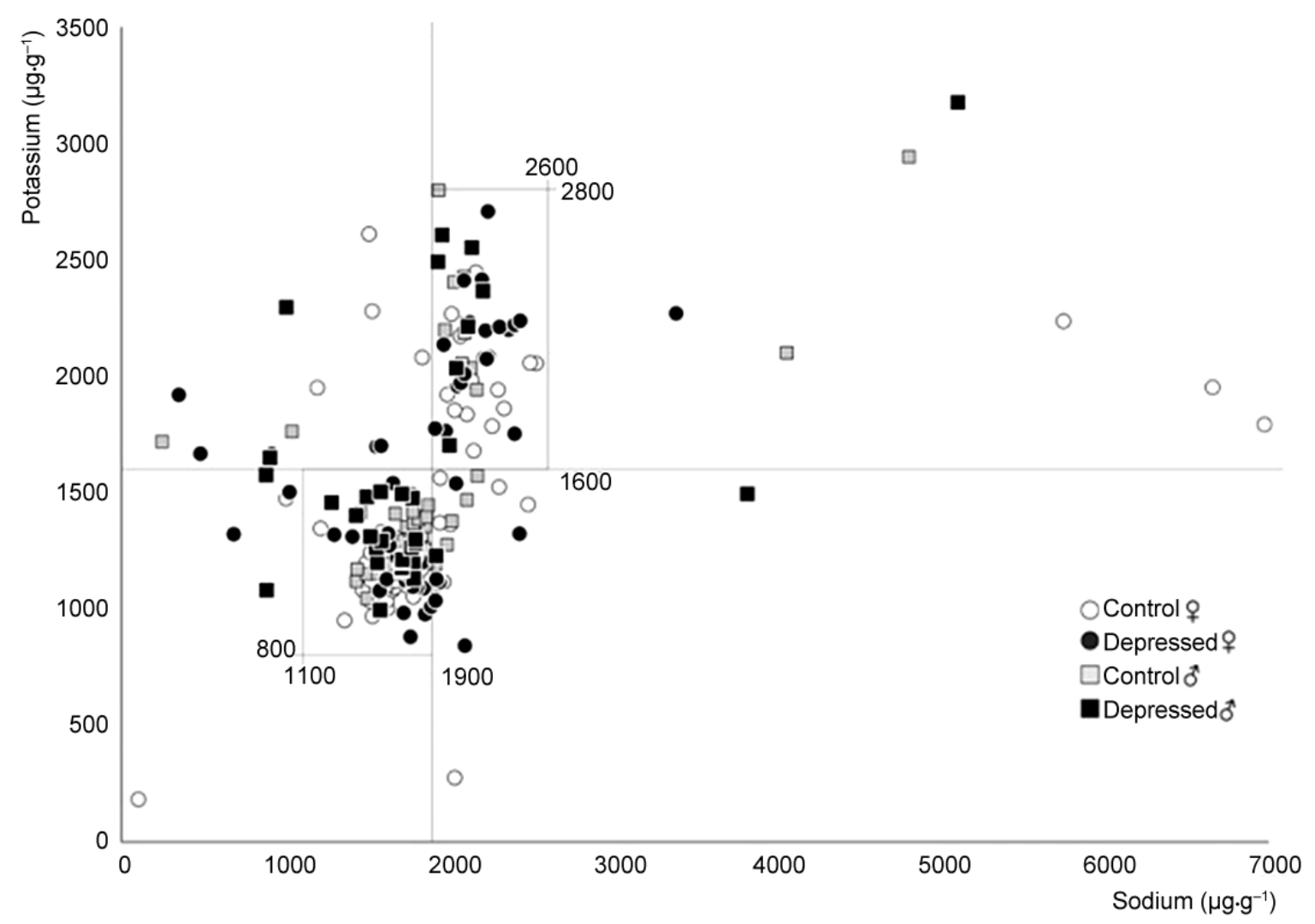

Figure 4.

Scatter plot of the whole blood sodium and potassium. $\square$ CM control men, $\square$ DM depressed men; ○ CW control women; $\bullet$ DW depressed women.

Tentative clusters are boxed: Low Na Low K cluster (left down), High Na High K cluster (upper right).

Table 4.

Hair Sodium median derivative concentrations (MDC) $\left(\mu \mathrm{g} \cdot \mathrm{g}^{-1}\right)$. Men $\left(\mathrm{D}_{1}-\mathrm{D}_{6}\right.$ downward MDC, $\mathrm{U}_{1}-\mathrm{U}_{6}$ upward MDC); Women ( $\mathrm{d}_{1}-\mathrm{d}_{6}$ downward MDC, $\mathrm{u}_{1}-\mathrm{u}_{6}$ upward MDC).

\begin{tabular}{cccccccccccc}
\hline \multicolumn{1}{c}{ MEN } \\
\hline \multicolumn{1}{c}{ Median $\left(\mathrm{M}_{0} \mathrm{n}_{123}=375.60 \mu \mathrm{g} \cdot \mathrm{g}^{-1} \mathrm{Na}\right)$} \\
\hline $\mathrm{MDC}$ & $\mathrm{n}$ & $\mathrm{Na}$ & $\mathrm{MDC}$ & $\mathrm{n}$ & $\mathrm{Na}$ & $\mathrm{MDC}$ & $\mathrm{n}$ & $\mathrm{Na}$ & $\mathrm{MDC}$ & $\mathrm{n}$ & $\mathrm{Na}$ \\
\hline $\mathrm{D}_{1}$ & 62 & 130 & $\mathrm{U}_{1}$ & 62 & 766 & $\mathrm{~d}_{1}$ & 94 & 86.3 & $\mathrm{u}_{1}$ & 94 & 473 \\
$\mathrm{D}_{2}$ & 31 & 75.7 & $\mathrm{U}_{2}$ & 31 & 1223 & $\mathrm{~d}_{2}$ & 47 & 49.6 & $\mathrm{u}_{2}$ & 47 & 909 \\
$\mathrm{D}_{3}$ & 16 & 56.5 & $\mathrm{U}_{3}$ & 16 & 1675 & $\mathrm{~d}_{3}$ & 24 & 28.8 & $\mathrm{u}_{3}$ & 24 & 1955 \\
$\mathrm{D}_{4}$ & 8 & 34.6 & $\mathrm{U}_{4}$ & 8 & 2331 & $\mathrm{~d}_{4}$ & 12 & 23.4 & $\mathrm{u}_{4}$ & 12 & 2150 \\
$\mathrm{D}_{5}$ & 4 & 20.6 & $\mathrm{U}_{5}$ & 4 & 2848 & $\mathrm{~d}_{5}$ & 6 & 13.7 & $\mathrm{u}_{5}$ & 6 & 2921 \\
$\mathrm{D}_{6}$ & 2 & 8.83 & $\mathrm{U}_{6}$ & 2 & 3189 & $\mathrm{~d}_{6}$ & 3 & 11.3 & $\mathrm{u}_{6}$ & 3 & 4763 \\
\hline
\end{tabular}

Note: Common Median $\left(\mathrm{M}_{0}\right) \mathrm{n}_{311}=242.50 \mu \mathrm{g} \cdot \mathrm{g}^{-1} \mathrm{Na}$. 
Table 5.

Hair Potassium median derivative concentrations (MDC) $\left(\mu \mathrm{g} \cdot \mathrm{g}^{-1}\right)$. Men $\left(\mathrm{D}_{1}-\mathrm{D}_{6}\right.$ downward $\mathrm{MDC}, \mathrm{U}_{1}-\mathrm{U}_{6}$ upward MDC); Women $\left(\mathrm{d}_{1}-\mathrm{d}_{6}\right.$ downward MDC, $\mathrm{u}_{1}-\mathrm{u}_{6}$ upward MDC).

\begin{tabular}{cccccccccccc}
\hline \multicolumn{1}{c}{ MEN } \\
\hline \multicolumn{3}{c}{ Median $\left(\mathrm{M}_{0} \mathrm{n}_{123}=130.00 \mu \mathrm{g} \cdot \mathrm{g}^{-1} \mathrm{~K}\right)$} & \multicolumn{5}{c}{ WOMEN } \\
\hline MDC & $\mathrm{n}$ & $\mathrm{K}$ & $\mathrm{MDC}$ & $\mathrm{n}$ & $\mathrm{K}$ & $\mathrm{MDC}$ & $\mathrm{n}$ & $\mathrm{K}$ & $\mathrm{MDC}$ & $\mathrm{n}$ & $\mathrm{K}$ \\
\hline $\mathrm{D}_{1}$ & 62 & 32.9 & $\mathrm{U}_{1}$ & 62 & 318 & $\mathrm{~d}_{1}$ & 94 & 25.2 & $\mathrm{u}_{1}$ & 94 & 183 \\
$\mathrm{D}_{2}$ & 31 & 16.4 & $\mathrm{U}_{2}$ & 31 & 1022 & $\mathrm{~d}_{2}$ & 47 & 14.8 & $\mathrm{u}_{2}$ & 47 & 401 \\
$\mathrm{D}_{3}$ & 16 & 12.0 & $\mathrm{U}_{3}$ & 16 & 1443 & $\mathrm{~d}_{3}$ & 24 & 10.1 & $\mathrm{u}_{3}$ & 24 & 736 \\
$\mathrm{D}_{4}$ & 8 & 5.74 & $\mathrm{U}_{4}$ & 8 & 1847 & $\mathrm{~d}_{4}$ & 12 & 6.08 & $\mathrm{u}_{4}$ & 12 & 960 \\
$\mathrm{D}_{5}$ & 4 & 4.13 & $\mathrm{U}_{5}$ & 4 & 2015 & $\mathrm{~d}_{5}$ & 6 & 4.8 & $\mathrm{u}_{5}$ & 6 & 1326 \\
$\mathrm{D}_{6}$ & 2 & 2.50 & $\mathrm{U}_{6}$ & 2 & 2687 & $\mathrm{~d}_{6}$ & 3 & 3.78 & $\mathrm{u}_{6}$ & 3 & 1775 \\
\hline
\end{tabular}

Note: Common Median $\left(\mathrm{M}_{0} \mathrm{n}_{311}=69.44 \mu \mathrm{g} \cdot \mathrm{g}^{-1} \mathrm{~K}\right)$.

(a) Sodium (Na)

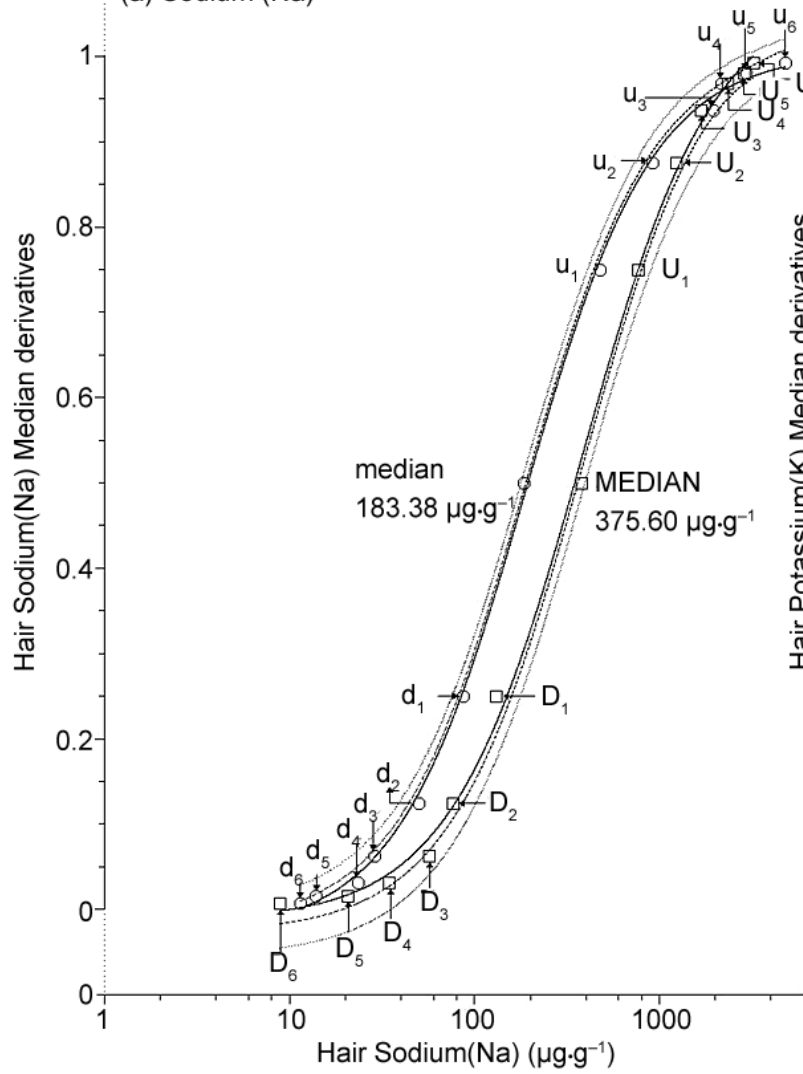

(b) Potassium (K)

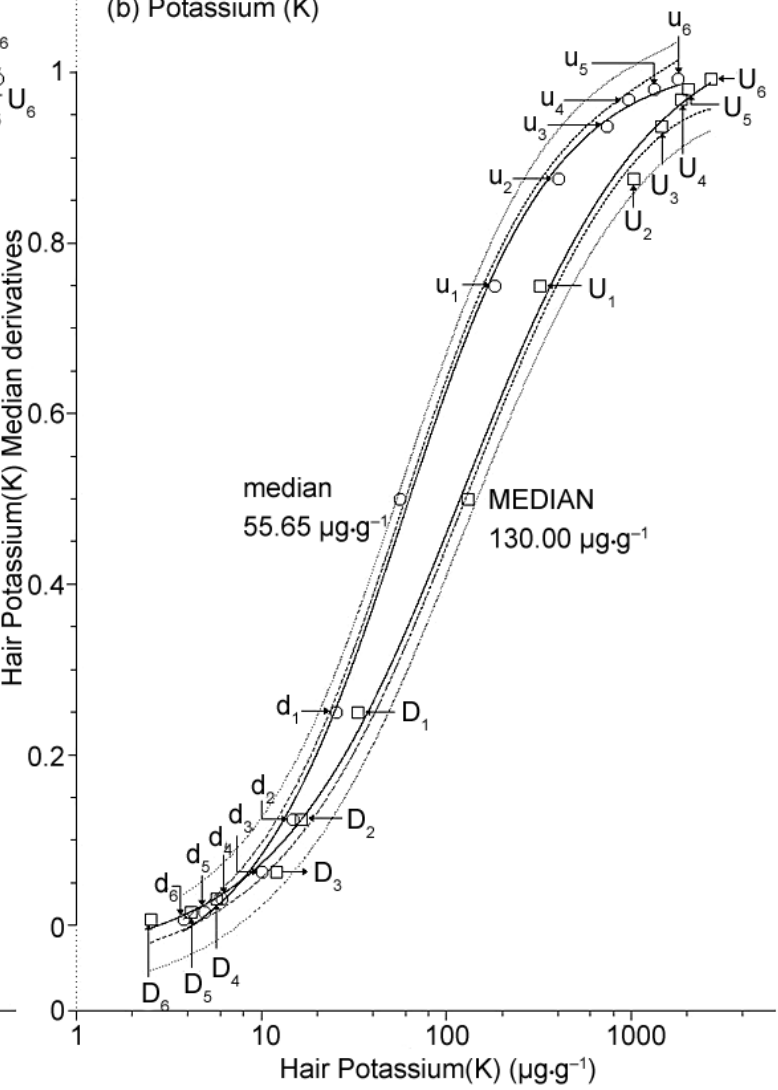

Figure 5.

(a) The difference between the hair Sodium median derivatives of Men $n=123$ ( $\square$ ) and Women $n=188$ ( $\circ$ ). D, U Men downward (D) and upward (U) median derivatives, d, u Women downward (d) and upward (u) median derivatives. $\cdots$ Logistic function:

$\mathrm{A}_{2}+\left(\mathrm{A}_{1}-\mathrm{A}_{2}\right) / 1+\left(\mathrm{X} / \mathrm{X}_{0}\right)^{p}, \cdots 0.95$ confidence limit, $\cdots 0.95$ prediction limit. Men: $\mathrm{Y}=1.075+(-.013-1.075) /\left[1+(\mathrm{X} / 381.737)^{1.223}\right]$

Women: $\mathrm{Y}=1.005+(-.029-1.005) /\left[1+(\mathrm{X} / 187.118)^{1.257}\right]$ (see Appendix for model and Table 4. for input values); (b) The difference between the hair Potassium median derivatives of Men $n=123$ (口) and Women $n=188(\circ)$. D, U Men downward (D) and upward (U) me-

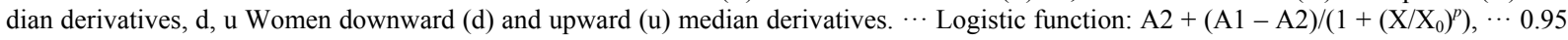
confidence limit, $\cdots 0.95$ prediction limit. Men: $\mathrm{Y}=1.060+(-.040-1.060) /\left[1+(\mathrm{X} / 123.81)^{0.86}\right]$, Women:

$\mathrm{Y}=1.013+(-.065-1.013) /\left[1+(\mathrm{X} / 57.455)^{1.054}\right]$ (see Appendix for model and Table 5 for input values).

hair earlier than men, and also reach saturation point earlier than men. The comparative logistic sigmoid curve, separately for men and women, showed that there were no apparent gender difference below the downward median derivatives $d_{3}$ and 
$\mathrm{D}_{3}$, and then again above the upward $\mathrm{u}_{2}$ and $\mathrm{U}_{2}$ median derivatives for women and men, respectively.

Similarly, the hair potassium $(\mathrm{H} \cdot \mathrm{K})$ below $14.8\left(\mathrm{~d}_{2}\right)$ and 16.4 $\left(D_{2}\right) \mu \mathrm{g} \cdot \mathrm{g}^{-1}$ for women and men, respectively, reflect low level of potassium intake. Then, again, there is a rapidly growing $\mathrm{H} \cdot \mathrm{K}$ saturation phase of two distinct, semi parallel saturation curves, first for women and then for men. Both saturation curves converge and plateau above $401\left(\mathrm{u}_{2}\right)$ and $1022\left(\mathrm{U}_{2}\right)$ $\mu \mathrm{g} \cdot \mathrm{g}^{-1}$ for women and men, respectively. It should be noted that the separation of convergent lines above the median is wider for potassium than sodium, i.e., the growing slope for potassium in men covers the wider range of concentrations than that for women. Thus, there are subtle differences between logistic regression curves not only between the men and women, but also between the sodium and potassium.

The levels of the antidiuretic hormone (ADH, vasopressin) were diminished in subjects who attempted suicide in compareson to the healthy control $(p<.01)$ (Table 6).

\section{Discussion}

Hair is the biological indicator tissue of great potential - it is easily accessible, collection is painless, can be simply stored to wait for analysis - and adequately reflects the metabolic changes due to the subtle changes of partition in the intermediary metabolism (Cutler 2004, Wilson 2010). Hair is the dynamic tissue structure-some hair follicles are active (anagen phase), the other are dormant (telogen phase), and some of them degenerate only to arise anew later on (Hordinsky, 2003). Hordinsky (2003) also showed that the rate of division of human hair follicle cells is second only to the bone marrow cells, which reflects accurately the metabolic changes within the body. Indeed, as the hair growth irreversibly from the follicle to the tip, it is a cumulative log of all the metabolic changes of the elements that pass through the follicle.

This study confirmed our preliminary observations that hair sodium and potassium concentrations are increased in the hair of depressed subjects (Momčilović et al., 2008, 2010). Moreover, this study showed the profound gender dependent metabolic difference in storing sodium and potassium in the hair; both elements were higher in men than women hair. We think that the observed changes of negative $\mathrm{Na}$ and $\mathrm{K}$ metabolic balance are related to the muscle inactivity of the depressed subjects. Indeed, the increased concentrations of hair sodium and potassium are not the results of the increased sodium and potassium intake in the depressed subjects, but are the conesquence of their impaired partition in the intermediary metabolism that favors sodium and potassium elimination from the body (negative balance) by the increased elimination via the hair. That hair elimination route appears to be enhanced by the decreased secretion of the vasopressin in subjects who attempted suicide (the gravest form of depression).

Our observation of increased hair $\mathrm{K}$ and $\mathrm{Na}$, i.e., their negative balance, and reduced serum vasopressin in depressed sub-

Table 6.

Plasma $\mathrm{ADH}^{*}$ in subjects who attempted suicide (Mean $\pm \mathrm{SD}$ ).

\begin{tabular}{cccc}
\hline & Subjects (n) & Men/Women & ADH $\left(\mathrm{pg} \cdot \mathrm{mL}^{-1}\right)$ \\
\hline Control & 19 & $7 / 12$ & $4.264^{\mathrm{a}} \pm 1.564$ \\
Attempted Suicide & 24 & $8 / 16$ & $3.376^{\mathrm{b}} \pm 1.567$ \\
\hline
\end{tabular}

Note: *ADH-antidiuretic hormone (vasopressin), ${ }^{\mathrm{a}, \mathrm{b}} \mathrm{M}$ Means bearing various superscripts in the same column differ significantly $(p<.01)$. jects are pattern-identical to those observed in astronauts after the short term Apollo space missions. Berry $(1973,1974)$ reported a slight decrease in total body water and a plasma volume decrease of almost eight percent accompanied with the decrease of total body exchangeable potassium of about ten percent. Fluid balance data for the Apollo 17 crew suggested that the observed major weight loss was body tissue loss and not attributable to water imbalance. Negative nitrogen and potassium balances confirmed that this tissue loss was principally a loss of body proteins, that is, muscle. Some of the weight loss observed must be attributed to a loss of fluid because of the slight decrease in total body water noted post-flight, confirmed by decreases in urinary electrolytes and antidiuretic hormone. The question emerges if the observed Earthly metabolic changes of body muscles in depressed subjects are the direct consequence of the muscle inactivity, or the fatigue of depresssion is mediated by the failure of some hypothetical, gravity dependent muscle mobility brain control "dynamostat" that operates in conjunction with the fluid regulation center that manifest its presence when being weightless in the Space. Thus, the muscle immobility of depression would be reflected by the increased amounts of available potassium and sodium due to the impaired partitioning processes of the intermediary metabolism.

Certainly, gravity plays an important alostatic (ongoing efforts to maintain homeostasis) role in the biology of cell life (McEwens, 2007) since it cued the organization of microtubular dissipative structures (Tabony \& Job, 1992). Indeed the intracellular fluid volume increased during the space flight (Leach et al., 1996), and what certainly increases the cell energy spending to keep the cellular osmotic volume; cells spent the most of their energy to keep their osmotic sustainability (Baumgarten \& Feher, 1988). Apparently, a lot of research is needed to elucidate the already observed contradictions in metabolism of electrolytes and hormones in relation to the motility and weightlessness (Lane \& Feeback, 2002). The observed gender difference in hair sodium and potassium reflects an addition to the already reported numerous differences observed in the body composition of women and men (Shills et al., 1999). Apparently, thus far, too little attention was paid to get down to the metabolic core of the gender differences in body composition; evident biological gender differences should not be confused with the gender rights to the political equality.

The molecular biology of major human depression, and the role of major electrolytes like sodium and potassium, is not well understood-certain aspects of depression result from maladaptive stress induced neuroplastic changes in specific neural circuits where KCNJ11 potassium inwardly rectifying channel J11 gene is involved (Krishnan \& Nestler, 2008). Indeed, Fava and Kendler (2000) summarized the research of Xie and McCobb (1998) on how adrenocorticotrophic hormones produced in the pituitary control the excitable properties of epinephrine-secreting cells of the adrenal gland by regulating alternative splicing of the $\mathrm{Ca}^{2+}$ - activate $\mathrm{K}^{+}$channel, Slo messenger RNA. Peripheral plasma levels of ADH (vasopressin) reflect osmotic regulation and activation of the magnocellular neurosecretory system, whereas the $\mathrm{ADH}$ physiological and behavioral role was mostly studied relative to the stress response of the hypothalamus-pituitary-adrenal (HPA) axis (de Winter et al., 2003). Thus, excess ADH increases aggressive behavior and improves mental alertness whereas ADH insufficiency adversely affects the circadian sleep rhythms and dorso- 
lateral neurons of the spine that control the motility (Caldwell et al., 2008). The muscle immobility of depression opens new research possibilities for the biological psychiatry. Further studies are needed to elucidate the role of other bioelements in the depression and to embrace their entangled gestalt with cellular osmosis, hormones, and physical activity control. Our results support the assumption of Caldwell et al. (2008) on diminished levels of ADH in depressed subjects.

\section{Conclusion}

Men accumulate more sodium and potassium in the hair than women.

Depressed subjects also accumulate more $\mathrm{Na}$ and $\mathrm{K}$ in the hair than the control subjects.

Antidiuretic hormone (ADH, vasopressin) is diminished in subjects who attempted suicide.

Muscle inactivity/immobility of depression mirrors the muscle waste of weightlessness.

\section{Acknowledgements}

This study was supported in part by the Croatian Ministry of Science, Education, and Sport grant No. 292-0222412-2405 (formerly No. 022-0222412-2405). The generous philanthropic support of the RCM, Isle of Man, UK to the first author is greatly appreciated.

\section{REFERENCES}

American Psychiatric Association (APA) (2000). Diagnostic and statistical manual of mental disorders (DSM IV). Washington, DC: Author.

Baumgarten, C. M., \& Feher, J. J. (1998). Osmosis and the regulation of cell volume. In N. Sperelakis (ed.), Cell physiology source book ( $2^{\text {nd }}$ ed., pp. 253-292). San Diego, CA: Academic Press.

Beers, M. H., \& Betkow, R. (1999). The Merck Manual of Diagnosis and Therapy $\left(17^{\text {th }}\right.$ ed.) Whitehouse Station, NJ: Merck, 1525-1544.

Berry, C. A. (1973). Weightlessness. In J. F. Parker, \& V. R. West, (eds.), Bioastronautics data book (pp. 349-415). Washington, DC: US Government Printing Office.

Berry, C. A. (1974). The medical legacy of Apollo. Aerospace Medicine, 45, 1046-1957.

Brown, M. (2009), Charter of rights is adopted in the UN, New York Times. URL.

http://www.nytimes.com/learning/general/onthisday/big//0618.html

Caldwell, H. K., Lee, H.-J., Macbeth, A. H., \& Young III, W. S. (2008). Vasopressin: Behavioral roles of an "original" Neuropeptide. Progress in Neurobiolog, 84, 1-24.

doi:10.1016/j.pneurobio.2007.10.007

Cutler, A. H. (2004). Hair test interpretation: Finding hidden toxicities. URL. http://www.noamalgam.com/buythebooks.html

De Winter, R. F. P., van Hemert, A. M, DeRijk, R. H. D., Zwinderman, K. H., Frankhuijzen-Sierevogel, A. C., Wiegant, V. M., \& Goekoop, J. G. (2003). Anxous-retarded depression: Relation with plasma vasopressin and cortisol. Neuropsychopharmacology, 28, 140-147. doi:10.1038/sj.npp.1300002

Fava, M., \& Kendler, K. S. (2000). Major depressive disorder. Neuron, 28, 335-341. doi:10.1016/S0896-6273(00)00112-4

Glantz, S. A. (2005). Primer of biostatistics (6th ed.). New York: McGraw Hill.

Glick, S. M., \& Kagan, A. (1979). Radioimmunoassay of arginine vasopressin. In B. M. Jaffe, \& H. R. Behrmann (Eds.), Methods of hormone radioimmunoassay. New York: Academic Press.
Hordinsky, M. K. (2003). Alopecia. In J. L. Bolognia, J. L. Jorizzo, \& R. P. Rapini (eds.), Dermatologia (pp. 1033-1059). Edinburgh: Mosby.

Kaplan, H. I., \& Sadock, B. J. (Eds.) (1995). Comprehensive textbook of Psychiatry $\left(6^{\text {th }}\right.$ ed.). Baltimore: Williams and Wilkins.

Kessler, R. C., McGonagle, K. A., Swartz, M., Blazer, D. G., \& Nelson, C. B. (1993). Sex and depression in the National Comorbidity Study Survey: Lifetime prevalence, chronicity, and recurrence. Journal of Affective Disorders, 29, 85-96. doi:10.1016/0165-0327(93)90026-G

Krishnan, V., \& Nestler, E. J. (2008). The molecular neurobiology of depression. Nature, 455, 894-902. doi:10.1038/nature07455

Lane, H. W., \& Feeback, D. L. (2002). Water and energy dietary requirements and endocrinology of human space flight. Nutrition, 18, 820-828. doi:10.1016/S0899-9007(02)00936-X

Leach, C. S., Alfrey, C., Suki, W. N., Leonard, J. I., Rambaut, P. C., \& Inners, L. D. (1996). Regulation of body fluid compartments during short-term space flight. Journal of Applied Physiology, 81, 105-116.

Licino, J., \& Wong, M.-L. (2005). Biology of depression (Preface). Weinheim: Wiley-VCH Verlag $\mathrm{GmbH}$ and Co. doi:10.1002/9783527619672

McEwens, B. S. (2007). Physiology and neurobiology of stress and adaptation: Central role of the brain. Physiological Reviews, 87, 873934. doi:10.1152/physrev.00041.2006

Momčilović, B. (2011). Are two heads better than one even if one is a cabbage?-Memories and reflections on the project peer review practices in Croatia. Periodicum biologorum, 113, 21-27.

Momčilović, B., Morović, J., Ivičić, N., \& Skalny, A. V. (2006). Hair and blood multielement profile for metabolic imaging of the major unipolar depression: Study rationale and design. Trace Elements in Medicine (Moscow), 7, 33-42.

Momčilović, B, Morović, J, Prejac, J, Skalny, A. V., \& Ivičić, N. (2008). Trace element profile of human depression-The tapestry of patterns. Trace elements and electrolytes, 25, 187-190.

Momčilović, B., Prejac, J., Brundić, S., Morović, S., Skalny, A. V., Mimica, N., \& Drpić, S. (2010). An essay on human and elements, multielement profiles, and depression. Translational Neuroscience, 1, 322-334. doi:10.2478/v10134-010-0039-2

Momčilović, B., Prejac, J., \& Ivičić, N. (2009). A case report on analytical reproducibility of the human multielement profile. A two years follow up. Trace Elements in Medicine (Moscow), 10, 33-38.

Momčilović, B., Prejac, J., Momčilović, R., Ivičić, N., Veber, D., \& Lykken, G. I. (2008). On the same element isotope mass number (pleiad) and the clusters of elements sharing the same mass numbers in the Periodic system-The "cheshya" (fish skin) model. Trace Elements in Medicine (Moscow), 9, 5-20.

Shills, M. E., Olsen, J. A., Shika, M., \& Ross, A. C. (1999). Modern nutrition in health and disease. Baltimore, MD: Williams and Wilkins, 751-771.

Smylevich, I., \& Dougherty, E. R. (2010). Probabilistic Boolean networks. Philadelphia, PA: Society for Industrial and Applied Mathematics, 227-241. doi:10.1137/1.9780898717631.ch6

Tabony, J., \& Job, D. (1992). Gravitational symmetry breaking in microtubular dissipative structures. Proceedings of the National Academy of Sciences, 89, 6948-6952. doi:10.1073/pnas.89.15.6948

Willson, L. (2010). Nutritional balancing and hair mineral analysis (4th ed.). URL. http://www.drlwilson.com

Wong, M.-L. (2005). History and epidemiology of depression. In J. Licino, \& M.-L. Wong (eds.), Biology of depression: From novel insights to therapeutics strategies (pp. 653-667). Weinheim: Wiley$\mathrm{VCH}$ Verlag $\mathrm{GmbH}$ and $\mathrm{Co}$.

Wulsin, L. R. (1996). Depressive disorders. In J. L. Jacobson, \& A. M. Jacobson (eds.), Psychiatric secrets (pp. 74-79). Philadelphia/St Louis: Hanley and Belfus Inc./Mosby.

Xie, J., \& McCobb, D. P. (1998). Control of alternative splicing of potassium channels by stress hormones. Science, 280, 443-446. doi:10.1126/science. 280.5362 .443 


\section{Appendix.}

The median derivatives model (Population Size, PS $=1.000$ ).

\begin{tabular}{|c|c|c|c|c|c|c|}
\hline \multicolumn{7}{|c|}{ MEDIAN (M0) } \\
\hline \multicolumn{7}{|c|}{$<$} \\
\hline \multicolumn{4}{|c|}{ Median Derivative Downward Branch } & \multicolumn{3}{|c|}{ Median Derivative Upward Branch } \\
\hline \multicolumn{4}{|c|}{$(\mathrm{D} 0, \mathrm{n}=155=\mathrm{PS} \quad 0.500)$} & \multicolumn{3}{|c|}{$(\mathrm{U} 0, \mathrm{n}=155=\mathrm{PS} \quad 0.500)$} \\
\hline \multicolumn{4}{|c|}{ Descending Median Derivatives } & \multicolumn{3}{|c|}{ Ascending Median Derivatives } \\
\hline & $\mathrm{D} 0 / 2$ & 0.250 & U1 & D0 & $\mathrm{A} 0 / 2$ & 0.750 \\
\hline $\mathrm{D} 2$ & $\mathrm{D} 0 / 4$ & 0.125 & $\mathrm{U} 2$ & $\mathrm{D} 0+$ & $10 / 4$ & 875 \\
\hline \multicolumn{7}{|c|}{ 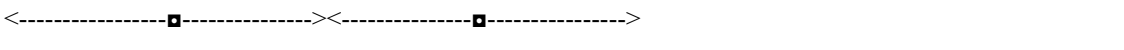 } \\
\hline D3 & D0/8 & 0.062 & & U3 & $\mathrm{D} 0+\mathrm{A} 0 / 8$ & 0.937 \\
\hline \multicolumn{7}{|c|}{ 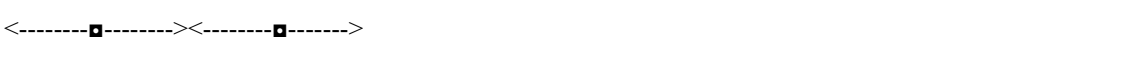 } \\
\hline D4 & D0/16 & 0.031 & & $\mathrm{U} 4$ & $\mathrm{D} 0+\mathrm{A} 0 / 16$ & 0.969 \\
\hline \multicolumn{7}{|c|}{ <-----0---->>----口---> } \\
\hline D5 & $\mathrm{D} 0 / 32$ & 0.016 & & U5 & $\mathrm{D} 0+\mathrm{A} 0 / 32$ & 0.983 \\
\hline --ם-- & & & & & & $--\mathbf{d - -}$ \\
\hline D6 & $\mathrm{D} 0 / 64$ & 0.008 & & U6 & $\mathrm{D} 0+\mathrm{A} 0 / 64$ & 0.992 \\
\hline$-\mathbf{0}-$ & & & & & & $-\mathbf{- D}$ \\
\hline
\end{tabular}

We studied the frequency distribution of the studied hair element median and it's derivatives to assess element's insufficiency, adequacy, and overexposure. First we assess the median (M0) hair silver concentration of our subject population. By definition, one half of the studied population was above the median (upward or ascending median branch, U0), and the other half was below the median (downward or descending median branch, D0). Hence, the population size (PS) for M0 is the sum of the respective upward and downward median branches around the central inflection "hinge" M0, i.e., PS $=\mathrm{U} 0+\mathrm{D} 0=0.5+$
$0.5=1.0$. Both the respective upward and downward median branches can be further divided in the same "median of median" way into a series of sequential median derivatives (U0, 1 , $2,3, \cdots, \mathrm{n}-1, \mathrm{n}$ and D0 $1,2,3, \cdots, \mathrm{n}-1, \mathrm{n}$ ) For every median derivative of the population, the actual hair silver concentration can be identified. Thus, instead of mechanically throwing the preconceived percentile grid upon the observed data, we inferred the median derivative grid out from the data set itself (Smylevich \& Dougherty, 2010). 